\title{
The Effect of Problem Based STEM Education on the Perception of 5th Grade Students of Engineering, Engineers and Technology
}

\author{
Ayşegül Ergün ${ }^{1 *}$, Erhan Külekci ${ }^{2}$ \\ ${ }^{1}$ Manisa Celal Bayar University, Faculty of Education, Department of Mathematics and Science Education, Demirci, \\ Manisa, TURKEY \\ ${ }_{2}^{2}$ Ministry of National Education, Cemil Atlas Middle School, Bayrakli, Izmir, TURKEY
}

*Corresponding Author: ergunaysegul@gmail.com

Citation: Ergün, A. and Külekci, E. (2019). The Effect of Problem Based STEM Education on the Perception of 5th Grade Students of Engineering, Engineers and Technology. Pedagogical Research, 4(3), em0037. https://doi.org/10.29333/pr/5842

Published: July 18, 2019

\begin{abstract}
It is important for students to experience STEM education for countries to be able to increase their scientific research capacity and economic progress. The purpose of this research was to determine the effect of problem based STEM education on the perception of middle-school $5^{\text {th }}$ grade students of engineering, engineers and technology. In the research, the single group pre-test and post-test experimental design which is one of the quantitative research methods was used. The study group of the research was consisted of 17 fifth grade students who were receiving education at a state school in the Akhisar district of the city of Manisa in the fall semester of the 2017-2018 academic year. The data of the research were collected with the What is Engineering? and What is Technology? surveys and Draw an Engineer Test. In the analysis of data, non-parametric tests, frequency and percentage analysis and descriptive analysis were used. Following the applications carried out in the research, it was determined that the perceptions of the students of engineering, engineers and technology were developed in the positive manner. In the pre-drawings of engineers, it was seen that the students mostly depicted repairmen or construction workers, whereas they gave place to engineering who produced and did design work in their post-drawings. In addition, it was seen that the perception of male engineers in the pre-drawings decreased in the post-drawings and that the perception of female engineers increased. It was determined that problem based STEM education was effective in terms of the students understanding that only electronical devices are not technology. In the light of the obtained results, suggestions were made about the effective use of problem based learning in the application of STEM education.
\end{abstract}

Keywords: STEM education, perception of engineering and engineers, perception of technology, problem based learning

\section{INTRODUCTION}

In today's world, the need for individuals who have 21 st century skills such as critical thinking, entrepreneurship, communication, cooperation, decision making, leadership, problem solving, responsibility and creativity has been constantly increasing one of the education approaches which has emerged to meet this need is STEM education. STEM education which is made up of the first letters of the words Science, Technology, Engineering and Mathematics (Gonzalez and Kuenzi, 2012) is an interdisciplinary approach which targets educating students in a holistic manner in the disciplines of science, technology, engineering and mathematics (Daugherty, 2013; Kuenzi, 2008). In STEM education, it is attempted to form a relationship between a real life 
problem and the subject and to integrate STEM disciplines. In STEM education, the four disciplines in question are adapted to the subject or one of the disciplines is focused on and the other disciplines are used as context to teach the subject of the discipline in focus (Moore et al., 2014).

One of the popular teaching methods used in STEM education is the engineering design process (Brophy, Klein, Portsmore and Rogers, 2008). While creating their designs in the engineering design process, students can express a problem they face in daily life in more than one manner or can produce multiple solutions to that problem. In the engineering design process, on the one hand students develop their engineering skills and understand and learn the relationship between science and technology better on the other hand (Kolodner, 2002). In the engineering design process, the steps of ask, imagine, plan, design and improve are used (Engineering is Elementary [EiE], 2018). The step of asking questions consists of asking accurate questions about the solution of the problem, defining the problem and determining the limitations related to the solution of the problem activities. The imagining step involves brain-storming about the solution students in which they need to find the possible solutions to the problem. In the planning step, students evaluate the produced ideas and choose the best method. Then, the diagrams related to the method are drawn and the required materials are prepared. In the designing step, the related plan is implemented and a design is created. Then, the design is tested. In the improving step, the tested and created designs are developed more and the incomplete parts of the designs are completed (Çavaş, Bulut, Holbrook and Rannikmae, 2013).

Since problem based learning (PBL) makes it possible for students to develop their skills and confidence in solving problems they have never seen before, it is suitable for the discipline of engineering and other STEM disciplines. The models developed by the students to solve problems, constructive and creative activities which involve qualitative or quantitative relationship allow students to deal with the problem with an interdisciplinary approach (Smith and Starfield, 1993). In these aspects, PBL is an extremely suitable approach for STEM education (Doppelt et al., 2008; Sadler, Coyle and Schwartz, 2000). When PBL is provided for the students in an integrated manner with the STEM application in the engineering design process, interdisciplinary learning which can increase content knowledge is achieved (Hmelo-Silver, 2004).

In the literature, there are studies in which PBL learning is used in STEM education (Dischino et al., 2011; Lou et al., 2011; Rehmat, 2015). For instance, in a study in which a program called STEM PBL was developed with the purpose of increasing students' interest in STEM careers, it was concluded that PBL develops students' critical thinking, cooperation and problem solving skills (Dischino et al., 2011). In another study, it was determined that the PBL method is effective in achieving STEM integration, in students' developing a positive attitude towards STEM and planning their future careers (Lou et al., 2011). In a study in which PBL's effect on students' field knowledge, critical thinking and attitude towards STEM was analyzed, it was found that experiment group students' attitude towards STEM and top level thinking skills significantly increased compared to the control group students (Rehmat, 2015).

In the literature, there are studies which analyze the effect of STEM education provided during the engineering design process on students' perception of science, engineering and technology as well (Cunningham and Lachapelle, 2010; Gülhan and Şahin, 2016; Lachapelle, Jocz and Phadnis, 2011; Lachapelle et al., 2012; Lachapelle et al., 2013; Pekmez, Y1lmaz, Alaçam Akşit and Güler, 2017). For instance, Cunningham and Lachapelle (2010) analyzed the effect of STEM education provided during the engineering design process on the understanding of middle-school students of engineering and science. As a result of the study, it was determined that the knowledge level of experiment group students on engineering and science increased in a positive manner compared to the control group. In another study in which the effect of STEM education on the views of $3^{\text {rd }} 4^{\text {th }}$ and $5^{\text {th }}$ grade students on technology, it was determined that the number of students who mostly associated technology with electricity in the pre-test decreased in the post-test (Lachapelle et al., 2013). Lachapelle et al. (2011) determined in their study that after STEM education provided during the engineering design process, the knowledge of $3^{\text {rd }}, 4^{\text {th }}$ and $5^{\text {th }}$ grade students on engineering and technology increased and that they developed a more positive attitude towards science and technology. In another study, the effect of STEM education on the interest of primary school students in science and engineering and their understanding of careers in this area were analyzed. In the study, it was determined that the understanding and attitude of the experiment group in which STEM education was given developed in a more positive manner compared to the control group. In addition, it was seen that the interest of male students in the career of engineering was more positive compared to female students in the pre-test, whereas the interest of the female students in the career of engineering increased as well in the post-test (Lachapelle et al., 2012). Pekmez et al. (2017) analyzed the effect of the education module titled "Engineering and Technology Lessons for Children" on the attitude in and perception of $4^{\text {th }}, 5^{\text {th }}$ and $6^{\text {th }}$ grade students of science, engineering and technology. After the STEM education given in the study, it was determined that the attitudes of $5^{\text {th }}$ and $6^{\text {th }}$ grade students towards science and engineering increased and that a significant increase took place in the knowledge levels of the students in all of the concerned grades about technology. In another study, it was determined that $5^{\text {th }}$ grade students' perception of, attitude towards and willingness to choose STEM careers, their 
conceptual comprehension level in the area of science and reflective thinking skills developed (Gülhan and Şahin, 2016).

According to the results obtained in the studies in question, it can be stated that the PBL approach and the engineering design process used in STEM education has positive effects on students' perception of, knowledge in, attitude towards STEM areas and different skills. In this research, since it was considered that the integration of PBL with the engineering design process would be effective in positively developing students' perception of engineering, engineers and technology, the PBL approach and the engineering design process in the implementation of STEM education were dealt with together. In this scope, the purpose of the research was to determine the effect of problem based learning on the perceptions of middle-school $5^{\text {th }}$ grade students of engineering, engineers and technology. In the study, the answers to the following questions were sought:

1. Does problem based STEM education have any effects on the students' perception of engineering?

2. Does problem based STEM education have any effects on the students' perception of engineers?

3. Does problem based STEM education have any effects on the students' perception of technology?

\section{METHODOLOGY}

\section{Research Design}

In the research, the single group pre-test and post-test experimental design was used. The experimental design is a research design in which the effect of at least one independent variable on one or more dependent variables is determined. In the single group pre-test and post-test experimental design, a group is applied the independent variable and the pre and post experiments evaluations are done (Cohen and Manion, 1997; Fraenkel and Wallen, 1996). The independent variable of this study was problem based STEM education and the dependent variables were perceptions of engineering, engineers and technology. The single group pre-test and post-test experimental design is one of the weakest experimental designs. However, in studies in which a new educational approach is used, it is stated that the preference of single group experimental design is due to the nature of the study (Creswell, 2012). Since the problem based STEM education given in the engineering design process is a new educational approach, the single group experimental design was used in this research.

\section{Study Group of the Research}

The study group of the research was consisted of 17 fifth grade students who were receiving education at a state school in the Akhisar district of the city of Manisa in the 2017-2018 academic year. In the selection of the study group, the convenience sampling method which is one of the purposeful sampling methods was used. According to Yildırım and Şimşek (2013), since researcher in this sampling method chooses a close and easily accessible case, this adds speed and practicality to the study. The distribution of the study group in terms of gender is given in Table 1.

Table 1. Distribution of the study group in terms of gender

\begin{tabular}{ccc}
\hline Gender & $\mathbf{N}$ & $\mathbf{\%}$ \\
\hline Male & 9 & 52.94 \\
\hline Female & 8 & 47.06 \\
\hline Total & 17 & 100 \\
\hline
\end{tabular}

According to Table 1, 52.94\% of the study group consists of male students and $47.06 \%$ consists of female students.

\section{Data Collection Tools}

The data of the study were collected with the What is Engineering? and What is Technology? surveys and Draw an Engineer Test.

\section{The What is Engineering? Survey}

The What is Engineering? survey is a measurement tool developed by Cunningham, Lachapelle and LindgrenStreicher (2005) to evaluate the engineering perceptions of primary school students. The survey consists of 16 visuals which belong to people who work in the work place and each contains short explanations underneath. A few visual examples in the survey can be defined as supervising structures, using machines and working as a team. It was aimed at obtaining data about the students' skill of accurately defining the work engineers do among the visuals. The survey was translated from English to Turkish by the researchers and a pilot study was carried out 
with 24 eighth grade students after the expert view was received. In the pilot study, it was seen that the survey was understandable and that it could be used in the study.

\section{The Draw an Engineer Test}

The test which was developed by Knight and Cunningham (2004) consists of open-ended questions besides drawings. On the one side of the test, the students are asked to draw an engineers in a box and name the engineer. On the other side of the test, there are 4 open-ended questions as: "What are the personal characteristics of the engineer you drew?" "How is this engineer' work environment?" "How kind of work does this engineer do?" and "What are the engineers you drew doing?"

\section{The What is Technology? Survey}

The What is Technology? survey was developed by Cunningham et al. (2005) with the purpose of determining the perceptions of primary students of technology. The survey consists of 16 visuals whose names are indicated underneath each. The students were asked to circle the visuals which they think is related to technology. A few visual examples in the survey can be defined as shoes, cell phones and parrots. It was aimed at obtaining data about the students' skill of accurately defining the examples of technology among the visuals. The survey was translated from English to Turkish by the researchers and a pilot study was carried out with 24 eighth grade students after the expert view was received. In the pilot study, it was seen that the survey was understandable and that it could be used in the study.

\section{Analysis of Data}

Prior to the analysis of data, the normalcy of the pre-test and post-test scores the students received from the What is Engineering? and What is Technology? surveys were analyzed with the Kolmogorov-Smirnov test. Since the result of the analysis was $p<.05$, it was determined that the data did not display normal distribution. In this respect, non-parametric statistical techniques were used considering the result of the normalcy test and the number of data in the group $(n<30)$. In the testing of the difference between the pre-test and post-test scores of the students in the What is Engineering? and What is Technology? surveys, the Wilcoxon signed ranks test was used. The What is Engineering? and What is Technology? Surveys, were evaluated by giving 1 point for each visual that was accurately chosen and 0 point for each inaccurately chosen visual or for each visual left empty.

In the evaluation of the students' drawings in the Draw an Engineer Test? prior to and after the problem based STEM education, the drawing control list developed by Fralick, Kearn, Thompson and Lyons (2009) was used. In the evaluation of data obtained from the checklist, descriptive analysis was used. Data obtained from descriptive analysis are evaluated in accordance with the pre-determined categories, interpreted systematically in an open manner and the results are presented following the analysis of a cause and effect relationship (Yıldırım and Şimşek, 2013). For the reliability of descriptive analysis, the data coded by the first researcher were coded by the second researcher as well and the intercoder reliability between the two researchers were calculated as $93 \%$ with Miles and Huberman's (2015) reliability control coding formula. According to Yıldırım and Şimşek (2013), when the intercoder reliability percentage in the reliability calculation is $70 \%$, it is regarded as having reached the reliability percentage. Therefore, the obtained values show that the coding reliability of the researchers is sufficient.

\section{Application}

The students were firstly given theoretical information about the engineering design process and its steps. The steps of the engineering design process were given as shown in Figure 1.

ASK
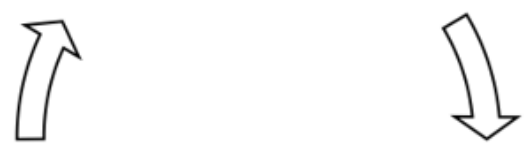

IMPROVE PLAN

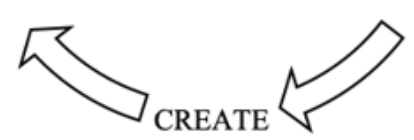

Figure 1. Steps of the engineering design process (EiE, 2018) 
According to the cycle in Figure 1, the student should firstly ask questions to identify the problem. Then, the student should think about how to solve the problem through imagining, plan to apply his/her thought and design it. As the students see the incomplete parts of their designs, they can redevelop and correct them. The problem based learning scenarios and the activities were applied according to the calendar given in Table 2 in line with the steps of engineering design process within the scope of $5^{\text {th }}$ grade "Measurement of Force and Friction" unit. The study was carried out in a total of 20 hours for 10 weeks in the science applications lesson which was given for two lesson hours per week.

Table 2. The application calendar of the study

\begin{tabular}{lll}
\hline Application date & Duration & Applications which were carried out \\
\hline 4-25 October 2017 & 6 hours & Application of the pre-tests \\
\hline 1 November 2017 & 2 hours & Teaching of the measurement of force subject \\
\hline 8 November 2017 & 2 hours & Teaching of the friction force subject \\
\hline 15 November -22 November 2017 & 4 hours & Carrying out of the parachute design activity \\
\hline 29 November -13 December 2017 & 6 hours & Application of the post-tests \\
\hline
\end{tabular}

According to the calendar in Table 2, first the students were given pre-tests. Then, the problem based learning scenarios were distributed to the heterogeneous groups. After the students read these scenarios, they tried to answer the questions underneath each scenario by having discussions with their group members under the guidance of their teachers. In order to find a solution to the daily life problem in the scenario, the students did research using various sources and brought the required materials for the design the following week. The designs were completed in the lesson hours within the scope of the engineering design process and the best design was exhibited. The post-tests were given at the end of the process.

\section{FINDINGS}

\section{Findings Related to the First Research Question}

The pre-test and post-test scores of the students in the What is Engineering? survey were compared with the Wilcoxon signed ranks test to determine the effect of problem based STEM education on the students' perception of engineering. The results of the analysis are given in Table 3.

Table 3. The results of the Wilcoxon signed ranks test related to the pre-test and post-test scores received from the What is Engineering? survey

\begin{tabular}{lccccc}
\hline $\begin{array}{l}\text { Post-test } \\
\text { Pre-test }\end{array}$ & N & Mean Ranks & Sum Ranks & Z & P \\
\cline { 1 - 4 } Negative Rank & $1^{\mathrm{a}}$ & 4.50 & -3.303 & 0.001 \\
\hline Positive Rank & $15^{\mathrm{b}}$ & 8.77 & 131.50 & \\
\hline Equal & $1^{\mathrm{c}}$ & & & & \\
\hline
\end{tabular}

a: post-test $<$ pre-test

b: post-test $>$ pre-test

c: post-test $=$ pre-test

According to the analysis results given in Table 3, there is a significant difference in favor of the post-test in the students' perception of engineering $(\mathrm{Z}=-3.303, p<.05)$. It was determined that the post-test scores of 15 students increased compared to the pre-test, 1 student's pre-test and post-test scores were equal and 1 student's post-test score was lower than his/her pre-test score. According to this, it can be stated that problem based STEM education contributes to the students' knowledge on engineering. The number of students who chose the visuals in the survey in the pre-test and post-test are given in Table 4. 
Table 4. The number of students who chose the visuals in the survey in the pre-test and post-test

\begin{tabular}{|c|c|c|c|}
\hline Improve machines & $\begin{array}{l}\text { Supervise } \\
\text { construction }\end{array}$ & Set up factories & Construct buildings \\
\hline $\begin{array}{l}\text { Pre-test: } 11 \\
\text { Post-test }: 17\end{array}$ & $\begin{array}{l}\text { Pre-test: } 12 \\
\text { Post-test }: 15\end{array}$ & $\begin{array}{l}\text { Pre-test: } 7 \\
\text { Post-test }: 10\end{array}$ & $\begin{array}{l}\text { Pre-test: } 11 \\
\text { Post-test: } 10\end{array}$ \\
\hline Drive machines & Arrange flowers & $\begin{array}{l}\text { Read about } \\
\text { inventions }\end{array}$ & $\begin{array}{l}\text { Designs ways to } \\
\text { clean water }\end{array}$ \\
\hline $\begin{array}{l}\text { Pre-test:9 } \\
\text { Post-test:2 }\end{array}$ & $\begin{array}{l}\text { Pre-test: } 1 \\
\text { Post-test:0 }\end{array}$ & $\begin{array}{l}\text { Pre-test: } 9 \\
\text { Post-test: } 12\end{array}$ & $\begin{array}{l}\text { Pre-test: } 7 \\
\text { Post-test }: 5\end{array}$ \\
\hline Work as a team & Make Pizza & Install wiring & Sell food \\
\hline $\begin{array}{l}\text { Pre-test } 14 \\
\text { Post-test } 14\end{array}$ & $\begin{array}{l}\text { Pre-test: } 2 \\
\text { Post-test: } 0\end{array}$ & $\begin{array}{l}\text { Pre-test: } 10 \\
\text { Post-test }: 3\end{array}$ & $\begin{array}{l}\text { Pre-test: } 1 \\
\text { Post-test:0 }\end{array}$ \\
\hline $\begin{array}{l}\text { Repair cars } \\
\text { Ren }\end{array}$ & Design things & Clean teeth & Teach children \\
\hline $\begin{array}{l}\text { Pre-test: } 8 \\
\text { Post-test: } 1\end{array}$ & $\begin{array}{l}\text { Pre-test: } 13 \\
\text { Post-test } 17\end{array}$ & $\begin{array}{l}\text { Pre-test: } 1 \\
\text { Post-test: } 0\end{array}$ & $\begin{array}{l}\text { Pre-test: } 1 \\
\text { Post-test: } 0\end{array}$ \\
\hline
\end{tabular}

According to Table 4, it was determined that the number of students who thought that engineers are people who engage in activities such as improving machines, supervising constructions, setting up factories, reading about inventions and designing things in the post-test increased in comparison to the pre-test. It was determined that using machines, installing wiring and repairing cars which are not a part of the work area of engineers were chosen by a lower number of students in the post-test compared to the pre-test. Although designing ways to clean water was an engineering activity, it was chosen by a lower number of students in the post-test compared to the pre-test. It was determined that working as a team activity was chosen by an equal number of students in the pre-test and post-test. Making pizza, arranging flowers, selling food, teaching children and cleaning teeth which are not engineering activities were observed to be chosen by a very few students in the pre-test and not chosen at all in the post-test.

The answers of the students to what kind of work engineers do question in the survey prior to and after the application were evaluated and the difference in the number of students who gave the correct answers to what engineers do is given in the graphic in Figure 2. 


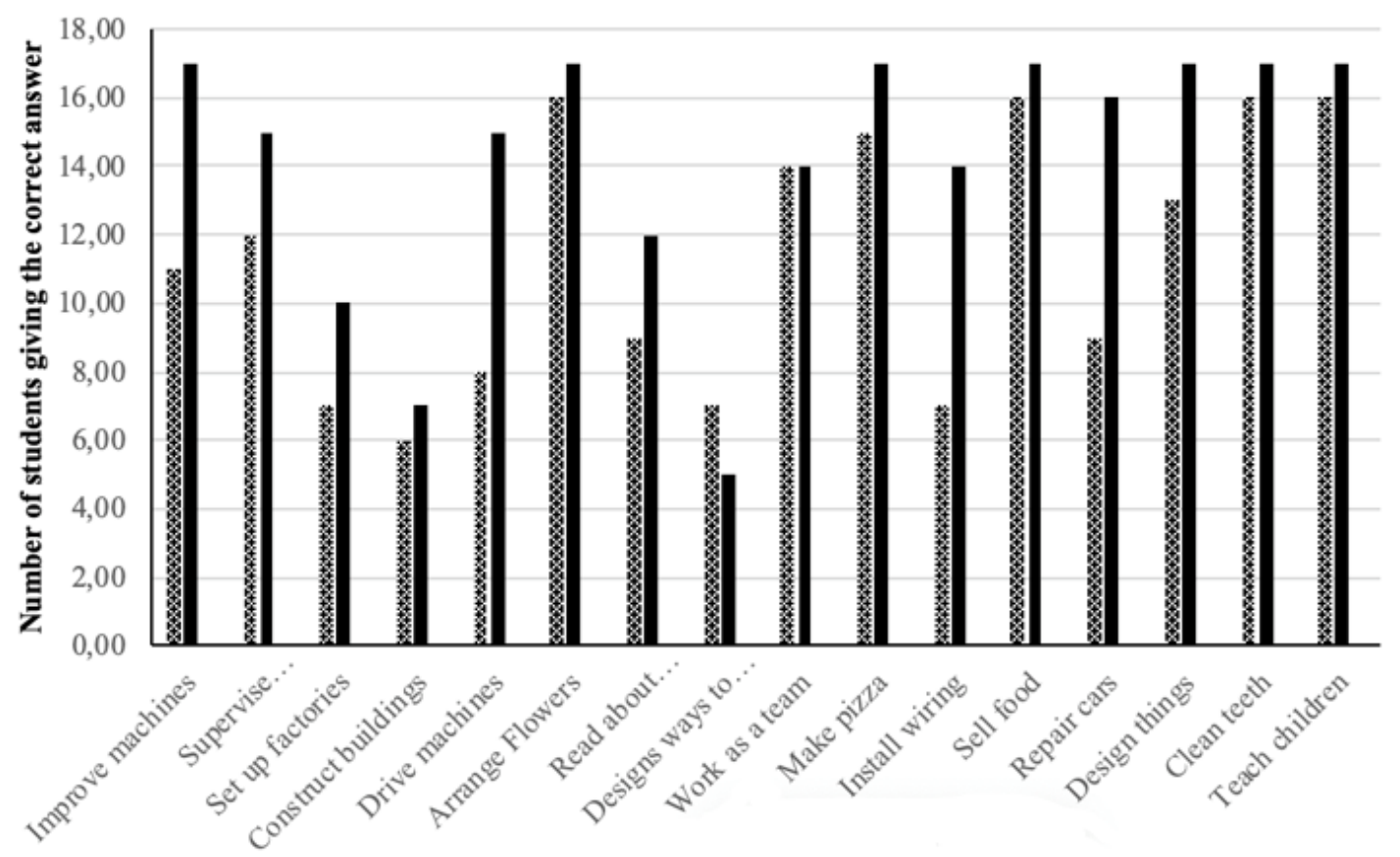

Figure 2. The number of students who have the correct answer to the items of the What is Engineering? survey in the pre and post tests

When the graphic in Figure 2 is analyzed, it can be seen that the number of students who accurately expressed activities of developing machines, supervising structures, founding factories, reading about the new innovations and designing thing in the pre-test is low, whereas the number of students who expressed these activities accurately in the post-test increased. Similarly, it was observed that the number of students who accurately chose the other activities increased in the post-test compared to the pre-test. Therefore, it can be stated that problem based STEM education affects the students' perception of engineering in a positive manner.

\section{Findings Related to the Second Research Question}

The pre and post engineer drawings of the students with the purpose of determining the effect of problem based STEM education on their perception of engineers were evaluated with the drawing control list developed by Fralick et al. (2009). The findings related to the physical characteristics of the engineers in the drawings were given in Table 5.

Table 5. Findings related to the physical characteristics of the engineers in the students' drawings

\begin{tabular}{|c|c|c|c|c|c|}
\hline \multirow{3}{*}{ Category } & \multirow{3}{*}{ Code } & \multicolumn{4}{|c|}{$5^{\text {th }}$ grade } \\
\hline & & \multicolumn{2}{|c|}{ Pre-drawing } & \multicolumn{2}{|c|}{ Post-drawing } \\
\hline & & $\mathrm{n}$ & $\%$ & $\mathrm{n}$ & $\%$ \\
\hline Type & Human & 17 & 100 & 17 & 100 \\
\hline \multirow{2}{*}{ Gender } & Male & 15 & 88.24 & 10 & 58.82 \\
\hline & Female & 2 & 11.76 & 7 & 41.18 \\
\hline \multirow{5}{*}{ Skin color } & Brown & 2 & 11.76 & 1 & 5.88 \\
\hline & Light pink & 7 & 41.18 & 9 & 52.94 \\
\hline & Yellow & 2 & 11.76 & 1 & 5.88 \\
\hline & None & 3 & 17.65 & 6 & 35.29 \\
\hline & Other & 3 & 17.65 & - & - \\
\hline \multirow{5}{*}{ Other physical characteristics } & Crazy hair style & 3 & 17.65 & - & - \\
\hline & Construction worker clothes & 2 & 11.76 & 1 & 5.88 \\
\hline & Safety/crash helmet & 1 & 5.88 & 4 & 23.53 \\
\hline & Bald & 5 & 29.41 & 3 & 17.65 \\
\hline & Other & 6 & 35.29 & 9 & 52.94 \\
\hline
\end{tabular}


When Table 5 is analyzed, it can be seen that the students drew all of the engineers as humans in the pre and post-drawings. In the pre-drawings, while the rate of male engineers was $88.24 \%$, the rate of female engineers was $11.76 \%$ and that the number of male engineers in the post-drawings decreased $(58.82 \%)$, whereas the number of female engineers increased $(41.18 \%)$. It was seen that the skin color of engineers in the pre and post drawings is mostly light pink or colorless. In the pre-drawings, the rate of engineers depicted with crazy hair styles was $17.65 \%$, whereas these kinds of hair styles were not given place to in the post-drawings and the number of bald engineers in the post-drawings decreased compared to the pre-drawings. It was determined that the rate of engineers with construction worker clothes was $11.76 \%$ in the pre-drawings, whereas this rate decreased to $5.88 \%$ in the postdrawings and the rate of engineers with helmets and head guards which was $5.88 \%$ in the pre-drawings increased to $23.53 \%$ in the post-drawings. The findings related to the work environments of engineers in the pre and postdrawings are given in Table 6.

Table 6. Findings related to the work environments of the engineers in the students' drawings

\begin{tabular}{|c|c|c|c|c|c|}
\hline \multirow{3}{*}{ Category } & \multirow{3}{*}{ Code } & \multicolumn{4}{|c|}{$\begin{array}{c}5^{\text {th }} \text { grade } \\
n=17\end{array}$} \\
\hline & & \multicolumn{2}{|c|}{ Pre-drawing } & \multicolumn{2}{|c|}{ Post-drawing } \\
\hline & & n & $\%$ & $\mathbf{n}$ & $\%$ \\
\hline \multirow{7}{*}{ Location } & Internal closed spaces & 8 & 47.05 & 7 & 41.18 \\
\hline & External/open Spaces & 7 & 41.18 & 6 & 35.29 \\
\hline & Space & 1 & 5.88 & - & - \\
\hline & Underground & - & - & - & - \\
\hline & Underwater & - & - & - & - \\
\hline & Not indicated & 1 & 5.88 & 4 & 23.53 \\
\hline & Total & 17 & 100 & 17 & 100 \\
\hline
\end{tabular}

According to Table 6, it was determined that the rate of closed spaces which was $47.05 \%$ in the pre-drawings decreased to $41.18 \%$ in the post-drawings, whereas the rate of open spaces which was $41.18 \%$ in the pre-drawings decreased to $35.29 \%$ in the post-drawings. While the students did not indicate the type of work space in the predrawings in the rate of $5.88 \%$, this rate increased to $23.53 \%$ in the post-drawings. It was determined that the students did not give place to underground and under water environments in the pre and post drawings. The findings related to the work engineers do in the pre and post drawings are given in Table 7.

Table 7. Findings related to the work engineers do in the students' drawings

\begin{tabular}{|c|c|c|c|c|c|}
\hline \multirow{3}{*}{ Category } & \multirow{3}{*}{ Code } & \multicolumn{4}{|c|}{$\begin{array}{c}5^{\text {th }} \text { grade } \\
n=17\end{array}$} \\
\hline & & \multicolumn{2}{|c|}{ Pre-drawing } & \multicolumn{2}{|c|}{ Post-drawing } \\
\hline & & $\mathrm{n}$ & $\%$ & $\mathbf{n}$ & $\%$ \\
\hline \multirow{9}{*}{$\begin{array}{l}\text { Inferences about the } \\
\text { work engineers do }\end{array}$} & Production/ Repair / Manual work & 10 & 58.82 & 7 & 41.18 \\
\hline & Operating / Using Machines and Tools & 1 & 5.88 & - & - \\
\hline & $\begin{array}{l}\text { Design/ Invention / Forming products/ } \\
\text { Creating products }\end{array}$ & 4 & 23.53 & 10 & 58.82 \\
\hline & Experiment/ Testing / Producing knowledge & - & - & - & - \\
\hline & Teaching / Explaining & - & - & - & - \\
\hline & Observing & 1 & 5.88 & - & - \\
\hline & No work or activity & - & - & - & - \\
\hline & Other & 1 & 5.88 & - & - \\
\hline & Total & 17 & 100 & 17 & 100 \\
\hline
\end{tabular}

According to Table 7, it was determined that $58.82 \%$ of the students depicted engineers as doing construction/repair/manual work in their pre-drawings, whereas this rate decreased to $41.18 \%$ in their postdrawings. While the work of design/invention/creation in the pre-drawings was depicted in the rate of $23.53 \%$, this rate increased to $58.82 \%$ in the post-drawings. It was seen that the students did not give place to experimenting or observation, producing knowledge or teaching activities in their pre and post-drawings. The findings related to the objects found in the work space of the engineers in the pre and post-drawings are given in Table 8. 
Table 8. Findings related to the objects found in the work space of engineers in the students' drawings

\begin{tabular}{|c|c|c|c|c|c|}
\hline \multirow{3}{*}{ Category } & \multirow{3}{*}{ Code } & \multicolumn{4}{|c|}{$\begin{array}{c}5^{\text {th }} \text { grade } \\
n=17\end{array}$} \\
\hline & & \multicolumn{2}{|c|}{ Pre-drawing } & \multicolumn{2}{|c|}{ Post-drawing } \\
\hline & & $\mathbf{f}$ & $\%$ & $\mathrm{f}$ & $\%$ \\
\hline \multirow{15}{*}{ Objects } & Other people & - & - & 2 & 6.45 \\
\hline & Robots & 1 & 5 & - & - \\
\hline & Computers & 6 & 30 & 2 & 6.45 \\
\hline & Architecture/Construction tools - wrench, hammer, etc. & 3 & 15 & 2 & 6.45 \\
\hline & Writing tools - paper, pens, etc. & - & - & 2 & 6.45 \\
\hline & Rocks & 1 & 5 & 1 & 3.23 \\
\hline & Construction tools & - & - & 2 & 6.45 \\
\hline & Flying vehicles & 2 & 10 & 2 & 6.45 \\
\hline & Rockets/ space vehicles & 2 & 10 & 3 & 9.68 \\
\hline & Imaginary machines & - & - & 4 & 12.90 \\
\hline & Other machines & 2 & 10 & 3 & 9.68 \\
\hline & Furniture - tables, chairs, etc. & - & - & 3 & 9.68 \\
\hline & Plans, drawings and graphics & 1 & 5 & 4 & 12.90 \\
\hline & Other & 2 & 10 & 1 & 3.23 \\
\hline & Total & 20 & 100 & 31 & 100 \\
\hline
\end{tabular}

According to Table 8, it was seen that the students did not give place to other people in their pre-drawings, whereas they gave place to other people in the rate of $6.45 \%$ in their post-drawings. While there are computers in the pre-drawings in the rate of $30 \%$, it was seen that this rate decreased to $6.45 \%$ in the post-drawings. While building and construction tools, tools such as wrenches and hammers were given place to in the pre-drawings in the rate of $15 \%$, this rate decreased to $6.45 \%$ in the post-drawings. It was seen that writing objects were not given place to in the pre-drawings and that objects such as paper and pencils were given place to in the rate of $6.45 \%$ in the post-drawings. It was determined that rockets, space ships and other machines were given place to by 2 students in the pre-drawings and by 3 students in the post-drawings. It was found that the rate of giving place to plans, drawings and graphics increased in the post-drawings compared to the pre-drawings. Examples of engineers from the students' pre and post-drawings are given in Figure 3. 


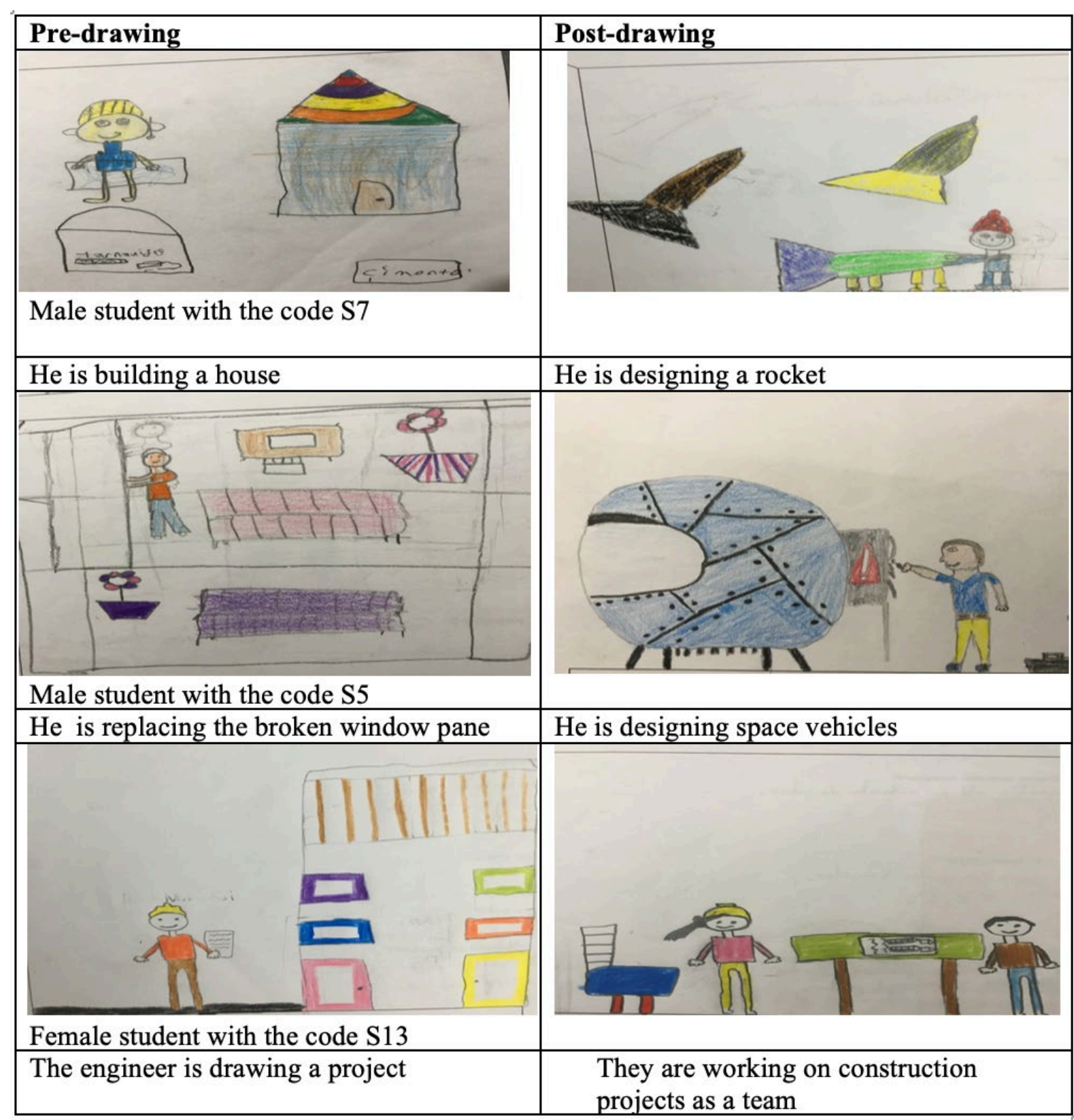

Figure 3. The sentences written by students with the codes S7, S5 and S13 about engineers and the work they do in their pre and post drawings

According to the drawings in Figure 3, the male student with the code S7 depicted the engineer as a person who is building a house in his pre-drawing, while he depicted the engineer as someone who is designing a rocket in his post-drawing. The male student with the code $\mathrm{S} 5$ depicted the engineers as a person who is replacing the broken window pane in his pre-drawing, he depicted the engineer as a person who is designing space vehicles in his post-drawing. The female student with the code S13 depicted the engineer in her pre-drawing as a person who is drawing a building project, whereas she depicted the engineer who is working on a project with a team in her post-drawing.

\section{Findings Related to the Third Research Question}

The pre and post test scores of the students they received from the What is Technology? survey given with the purpose of identifying the effect of problem based STEM education on the students' perception of technology were compared with the Wilcoxon signed ranks test. The results of the analysis are given in Table 9. 
Table 9. Results of the Wilcoxon signed ranks test analysis related to the pre and post test scores of the What is Technology? survey

\begin{tabular}{|c|c|c|c|c|c|}
\hline $\begin{array}{l}\text { Post-test } \\
\text { Pre-test }\end{array}$ & $\mathbf{N}$ & Mean Ranks & $\begin{array}{c}\text { Sum } \\
\text { Ranks }\end{array}$ & $\mathrm{Z}$ & $p$ \\
\hline Negative Rank & $0^{\mathrm{a}}$ & .00 & .00 & & \\
\hline Positive Rank & $17^{\mathrm{b}}$ & 9 & 153 & -3.632 & 0.000 \\
\hline Equal & $0^{c}$ & & & & \\
\hline
\end{tabular}

a: post-test $<$ pre-test

b: post-test $>$ pre-test

c: post-test $=$ pre-test

As it can be seen in Table 9, it was determined that there was a significant difference in the favor of the posttest in the students' perception of technology $(Z=-3.632, p<0.05)$. It was determined that the post-test score of all the students increased compared to the pre-test. According to this, it can be stated that problem based STEM education positively contributes to the knowledge of the students' on technology. The number of students who chose the visuals in the survey in the pre-test and post-test are given in Table 10.

Table 10. The number of students who chose the visuals in the What is Technology? survey in the pre-test and post-test

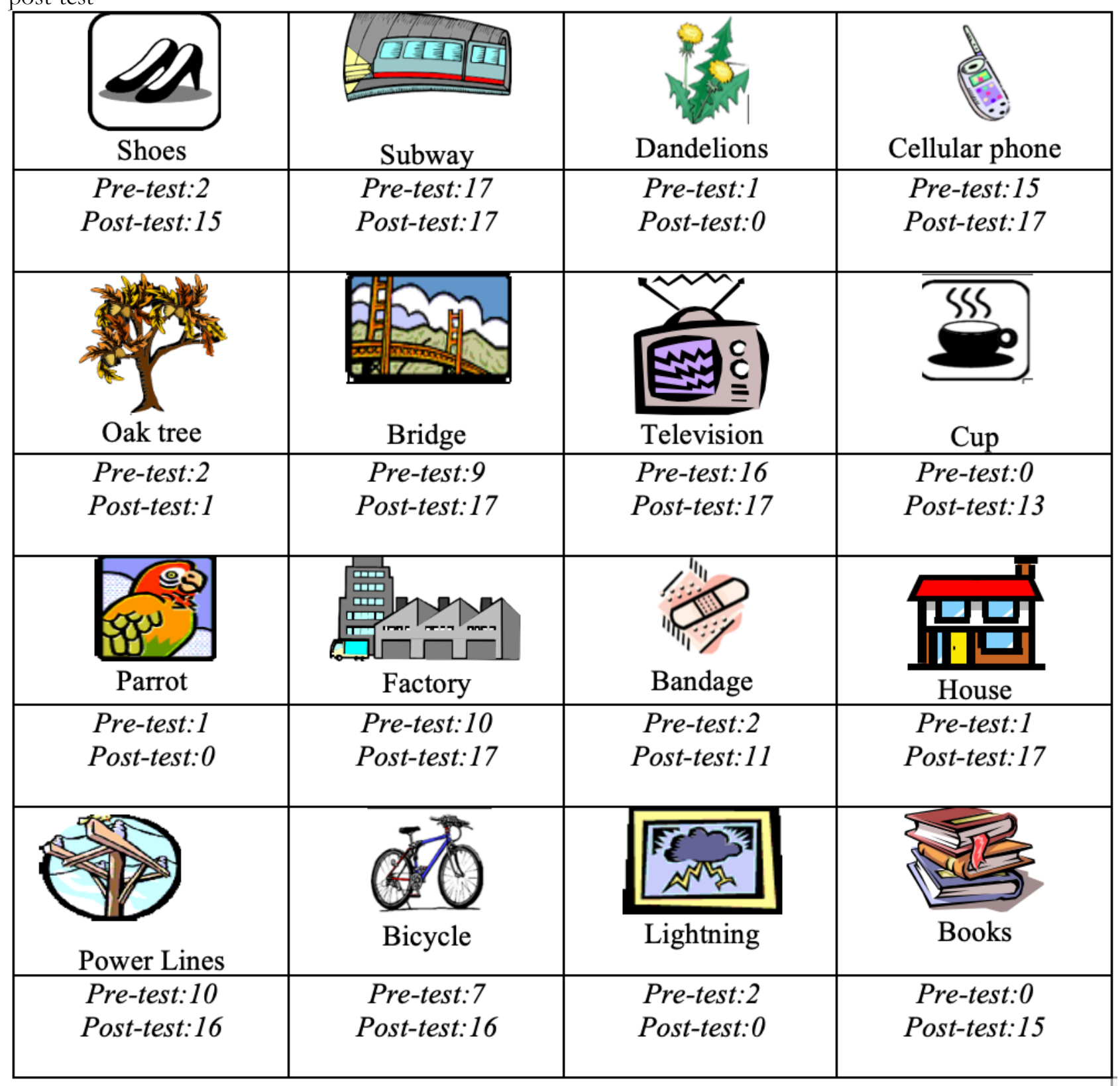


According to Table 10, the number of students who expressed that shoes, cups, factories, bandages, houses, power lines, bicycles, bridges and books are technology increased significantly in the post-test compared to the pre-test. While an equal number of students chose the subway in the pre-test and post-test, it was determined that the number of students who chose cell phones and televisions increased both in the pre-test and the post-test. Dandelions, oak trees, parrots and lightning visuals which are technology were chosen by 1-2 students in the pretest, whereas none of the visuals were chosen in the post-test with the exception of oak trees.

The evaluations of the markings of the students about whether the objects given in the What is Technology? survey are technology or not prior to and after the application were evaluated and the difference in the number of students who accurately answered the question about the objects are given in the graphic in Figure 4.

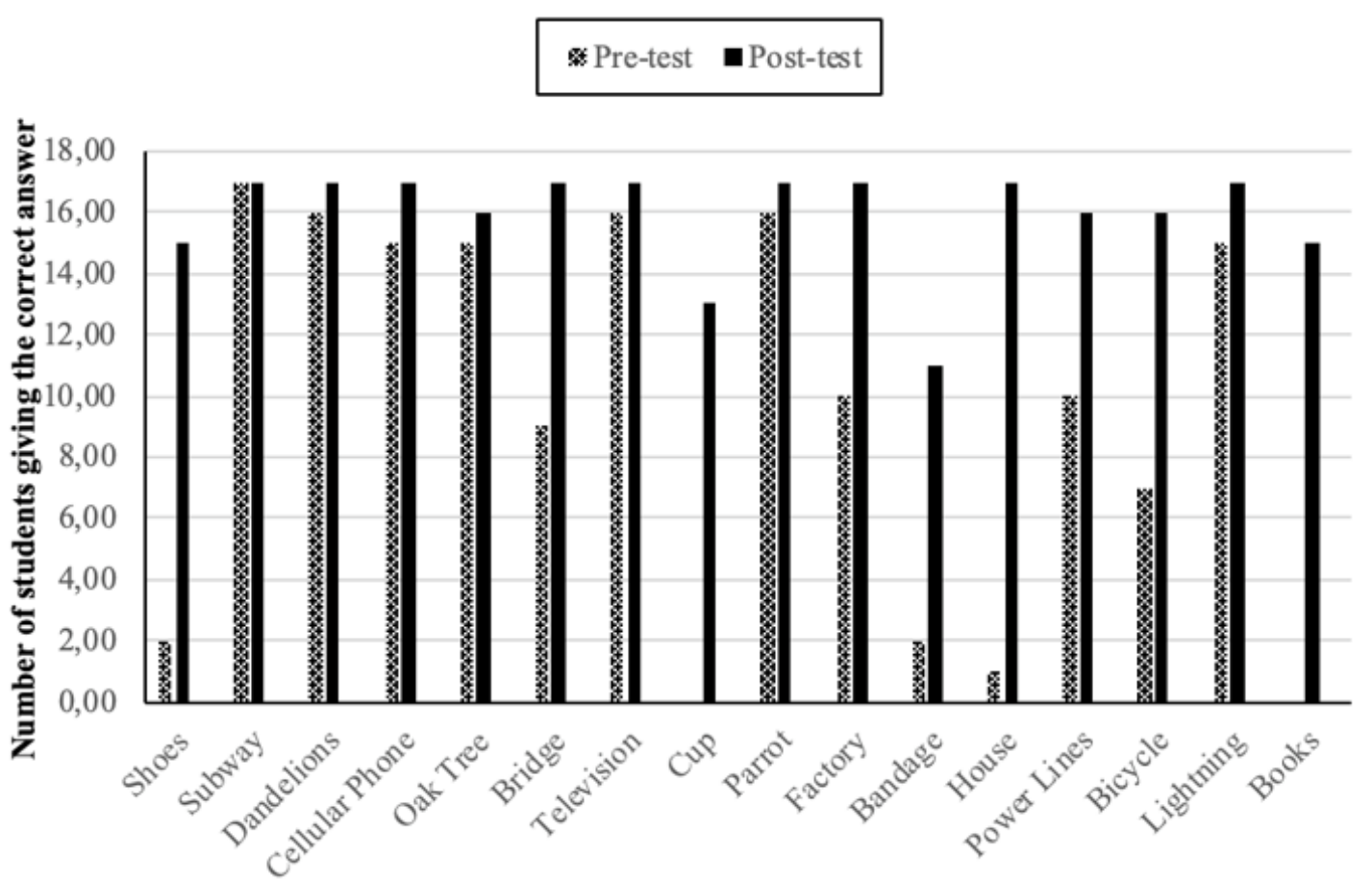

Figure 4. The number of students who accurately answered the question about the objects in the What is Technology? survey in the pre and post tests

When the graphic in Figure 4 is analyzed, it was determined that the number of students who expressed that things such as shoes, bridges, bandages, cups, houses, power lines, bicycles and books are technology are low in the pre-test, whereas the number of students who stated that these are technology increased in the post-test. Therefore, it can be stated that problem based STEM education positively affects the students' perception of technology.

\section{DISCUSSION, CONCLUSION AND SUGGESTIONS}

It was determined as a result of the study that problem based STEM education positively affected the engineering perception of $5^{\text {th }}$ grade students. It was determined that the number of students who accurately stated developing machines, supervising buildings, founding factories, reading about new inventions and designing things in the What is Engineering? survey pre-test was low and the number of students who accurately stated these in the post-test increased. In addition, the number of students who stated that laying cables and repairing cars which were stated as engineering activities in the pre-test were not engineering activities increased in the post-test. These findings obtained in this study are similar to the findings of other studies in the literature (Cunningham and Lachapelle, 2010; Gülhan and Şahin, 2016; Irkıçatal, 2016; Lachapelle et al., 2011; Lachapelle et al., 2012; Pekmez et al., 2017). For instance, Cunningham and Lachapelle (2010) reached the conclusion in their study that the STEM education they provided during the engineering design process increased students' knowledge level on engineering. Similarly, it was determined that the engineering knowledge of $3^{\text {rd }}, 4^{\text {th }}$ and $5^{\text {th }}$ grade students increased, they developed a positive attitude towards engineering after STEM education (Lachapelle et al., 2011) and that although the interest of male students in the engineering career was more positive compared to the female students in the pre-test, the interest of female students in the engineering career increased in the post-test (Lachapelle et al., 2012). Irkıçatal (2016) determined in her study that after school STEM activities she has carried out in line with the 
engineering design process positively affected students' perception of engineers. In Pekmez et al.'s (2017) study, it was concluded that STEM education carried out during the engineering design process created a significant increase in the engineering knowledge of $4^{\text {th }}, 5^{\text {th }}$ and $6^{\text {th }}$ grade students.

In the study, the students' engineer drawings were evaluated prior to and after problem based STEM education and the change in their perception of engineers was analyzed. As a result, it was determined that the rate of students who depicted engineers mostly as male in the pre-drawings (88.24\%) decreased in the post-drawings (58.82\%) and that the rate of female engineers in the pre-drawings $(11.76 \%)$ increased in the post-drawings $(41.18 \%)$. Therefore, it can be stated that the applications carried out in the study were effective in decreasing the stereotypical perceptions of the students of the gender of engineers. There are studies in the literature which support this result (Ganesh, 2011; Gülhan and Şahin, 2016). The students' perceptions of engineering are quite effective on their point of view on the engineering career (Knezek et al., 2015). Therefore, it can be stated that problem based STEM education can be effective in students' choosing the engineering career in the future.

In the study, it was determined that the rate of engineers with construction worker clothes in the pre-drawings $(11.76 \%)$ decreased in the post-drawings (5.88\%) and the rate of engineers with helmets or head guards in the predrawings $(5.88 \%)$ increased in the post-drawings $(23.53 \%)$. Taking the decrease in the rate of engineers with construction worker clothes, it can be stated that the perception that engineers do the same work with construction workers or repairmen decreased. The increase in the number of engineers with helmets or head guards can be interpreted as the students' lack of knowledge about the work areas of engineering and mostly know about construction engineering. While the students mostly depicted engineers in their pre-drawings in closed spaces $(47.05 \%)$, it was seen that this rate decreased in the post-drawings $(41.18 \%)$. Similarly, it was seen that the rate of giving place to open spaces in the pre-drawings (41.18\%) decreased in the post-drawings (35.29\%). It can be stated that open spaces being given less place to in the post-drawings overlaps with the finding of giving less place to engineers with construction worker clothes and that the students' perception of engineers who do construction or repair work in open spaces decreased. In support of this result, it was seen that the rate of engineers who did construction/repair/manual work in the pre-drawings (58.82\%) decreased in the post-drawings (41.18\%) and that the rate of engineers who did product design/invention/creation work in the pre-drawings $(23.53 \%)$ increased in the post-drawings $(58.82 \%)$. In parallel to these results, it was seen that building and the rate of construction tools and tools such as wrenches and hammers in the pre-drawings (15\%) decreased in the post-drawings $(6.45 \%)$ and that while writing materials were not given place to the in the pre-drawings, materials such as paper and pencils were given place to in the post-drawings $(6.45 \%)$. It was determined that rockets, space ships and other machines were given place to by 2 students in the pre-drawings and by 3 students in the post-drawings. It can be stated that the parachute design activity given to the students which is related to aviation and space engineering carried out in the study was effective for this finding. It was determined that the students did not give place to humans in their pre-drawings, whereas they included humans in their post-drawings. Therefore, it can be stated that the activities carried out in cooperating teams in the study were effective in the students understanding that engineering is an occupation which requires team work. As a result, it can be expressed that problem based STEM activities are effective in decreasing the students' perception of engineers as people who do repair and construction work and in increasing their perception of engineers as people who do design and inventions. Studies which state that through engineering based STEM education, the design dimension of engineering can be better understood also support this result (Carr and Diefes-Dux, 2012; Lyons and Thompson, 2005). The conclusion reached in the study that STEM education positively develops the students' perception of engineering is similar to the results of other studies in the literature (Gülhan and Şahin, 2016; Lyons and Thompson, 2005). For instance, Gülhan and Şahin (2016) stated in his study that the experiment group students who were given STEM education mostly drew engineers who "built houses/did construction work" in their pre-drawings, whereas their perception of engineers changed into people who "made drawings/designs" in their post-drawings.

As a result of the study, it was determined that problem based STEM education positively affected the perception of $5^{\text {th }}$ grade students of technology. It was determined that the number of students who expressed that things such as shoes, bridges, bandages, cups, houses, power lines, bicycles and books are technology was low in the pre-test of the What is Technology? survey, whereas the number of students who stated that these are technology increased in the post-test. Therefore, it can be stated that problem based STEM education was effective in students understanding that technology is not only electrical tools and it positively affected their perception of technology. This result obtained in the study is similar to the results of other studies (Lachapelle et al., 2011; Lachapelle et al., 2013; Pekmez et al., 2017). For instance, Lachapelle et al. (2011) stated that the knowledge of 3rd, $4^{\text {th }}$ and $5^{\text {th }}$ grade students on technology increased after STEM education given during the engineering design process in another study in which the effect of STEM education on the students' views on technology, it was determined that the number of students who mostly associated technology with electricity in the pre-test decreased in the post-test (Lachapelle et al., 2013). Similarly, it was determined that the education module titled "Engineering 
and Technology Lessons for Children" created a significant increase in the attitude and knowledge level of $4^{\text {th }}, 5^{\text {th }}$ and $6^{\text {th }}$ grade students in terms of technology (Pekmez et al., 2017).

As a result, the use of problem based learning and the engineering design process in the application of STEM education in the study was effective in the students' better comprehending the design dimension of engineering. It was determined that design applications positively developed the students' perception of technology. It can be stated that problem based STEM education was effective in positively developing the students' perception of STEM areas and knowledge levels. In the light of the results of the study, these are the suggestions made to the teachers: By forming connections with other disciplines in science lessons, interdisciplinary STEM education should be given place to. Problem based STEM education applications can be carried out at all grade levels and in chemistry and biology subjects of science lessons as well. The applications in question should be carried out cooperating teams. In order to be able to develop students' perceptions of engineering and technology, engineers working different areas can be invited to classes and can be made to directly communicate with the students. In the light of the results obtained from the study, the suggestions made to the researchers are as follows: New studies should be carried out with different study groups, subject areas and research methods. The students should be interviewed and their positive or negative views on STEM education should be identified. Through longitudinal and long-term studies, the tendency of students receiving STEM education in gravitating towards STEM areas and choosing these as their careers should be determined.

\section{ACKNOWLEDGEMENTS}

This research is part of Kulekci' master's thesis at Manisa Celal Bayar University.

\section{REFERENCES}

Brophy, S., Klein, S., Portsmore, M. and Rogers, C. (2008). Advancing engineering education in P-12 classrooms. Journal of Engineering Education, 97(3), 369-387. https://doi.org/10.1002/j.2168-9830.2008.tb00985.x

Carr, R. L. and Diefes-Dux, H. A. (2012). Change in elementary student conceptions of engineering following an intervation as seen from the draw-an-engineer test. Paper presented at 2012 ASEE Annual Conference, San Antonio, Texas.

Çavaş, B., Bulut, Ç., Holbrook, J. and Rannikmae, M. (2013). Fen eğitimine mühendislik odaklı bir yaklaşım: ENGINEER projesi ve uygulamaları. Fen Bilimleri Ögretimi Dergisi, 1(1), 12-22.

Cohen, L. and Manion, L. (1997). Research methods in education (4th ed.). Routledge: London and New York.

Creswell, J. W. (2012). Educational research: Planning, conducting, and evaluating quantitative and qualitative research (4th ed.). Boston: Pearson.

Cunningham, C. and Lachapelle, C. (2010). The impact of engineering is elementary (EiE) on students' attitudes toward engineering and science. In American Society for engineering education. American Society for Engineering Education.

Cunningham, C. M., Lachapelle, C. and Lindgren-Streicher, A. (2005). Assessing elementary school students' conceptions of engineering and technology. In Proceedings of the Annual conference of the American Society of Engineering Education. Portland, OR

Daugherty, M. K. (2013). The prospect of an "A" in STEM education. Journal of STEM Education, 14 (2), 10-15.

Dischino, M., DeLaura, J. A., Donnelly, J., Massa, N. M. and Hanes, F. (2011). Increasing the STEM pipeline through problem-based learning. Technology Interface International Journal, 12(1), 21-29.

Doppelt, Y., Mehalik, M. M., Schunn, C. D., Silk, E. and Krysinski, D. (2008). Engagement and achievements: A case study of design-based learning in a science context. Journal of Technology Education, 19(2), 22-39.

Engineering is Elementary (EiE) (2018). Engineering Design Process. Retrieved May 28, 2019, from http://eie.org/overview/engineering-design-process

Fraenkel, J. R. and Wallen, N. E. (1996). How to design and evaluate research in education (3th ed ). Mc Graw Hill Higher Education. New York, ABD.

Fralick, B., Kearn, J., Thompson, S. and Lyons, J. (2009). How middle schoolers draw engineers and scientists. Journal of Science Education and Technology, 18(1), 60-73. https://doi.org/10.1007/s10956-008-9133-3

Ganesh, T. G. (2011, January). Analyzing subject-produced drawings: the use of the draw-an-engineer assessment in context. In ASEE Annual Conference and Exposition, Conference Proceedings.

Gonzales, H. B. and Kuenzi, J. J. (2012). Science, technology, engineering, and mathematics (STEM) education: A primer Congressional Research Service. Retrieved on May 28, 2019, from http://www.stemedcoalition.org/wpcontent/uploads/2010/05/STEM-Education-Primer.pdf 
Gülhan, F. and Şahin, F. (2016). Fen-teknoloji-mühendislik-matematik entegrasyonunun (STEM) 5. sinıf öğrencilerinin kavramsal anlamalarına ve mesleklerle ilgili görüşlerine etkisi. Pegem Atıf İndeksi, $283-302$. https://doi.org/10.14527/9786053183563.019

Hmelo-Silver, C. E. (2004) Problem-based learning: What and how do students learn? Educational Psychology Review, 16(3), 235-266. https://doi.org/10.1023/B:EDPR.0000034022.16470.f3

Knezek, G., Christensen, R., Tyler-Wood, T. and Gibson, D. (2015). Gender differences in conceptualizations of STEM career interest: Complementary perspectives from data mining, multivariate data analysis and multidimensional scaling. Journal of STEM Education: Innovations and Research, 16(4), 13-19.

Knight, M. and Cunningham, C.M. (2004). Draw an Engineer Test (D AET): Development of a tool to investigate students' ideas about engineers and engineering. In American Society of Engineering Education. Salt Lake City, UT.

Kolodner, J. L. (2002). Facilitating the learning of design practices: lessons learned from an inquiry into science education. Journal of Industrial Teacher Education, 39(3), 9-40.

Kuenzi, J. J. (2008). Science, technology, engineering, and mathematics (STEM) education: Background, federal policy, and legislative action [Report for Congress]. Retrieved May 28, 2019, from https:/ / fas.org/sgp/crs/misc/RL33434.pdf

Lachapelle, C. P., Hertel, J. D., Jocz, J. and Cunningham, C. M. (2013). Measuring students' naive conceptions about technology. In NARST Annual International Conference, Rio Grande, Puerto Rico.

Lachapelle, C. P., Jocz, J. and Phadnis, P. (2011). An evaluation of the implementation of Engineering is Elementary in fourteen Minneapolis Public Schools. Boston, MA: Museum of Science.

Lachapelle, C. P., Phadnis, P. S., Jocz, J. and Cunningham, C. M. (2012). The impact of engineering curriculum units on students' interest in engineering and science. In NARST annual international conference, Indianapolis, IN.

Lou, S. J., Shih, R. C., Diez, C. R. and Tseng, K. H. (2011). The impact of problem-based learning strategies on STEM knowledge integration and attitudes: an exploratory study among female Taiwanese senior high school students. International Journal of Technology and Design Education, 21(2), 195-215. https://doi.org/10.1007/s10798010-9114-8

Lyons, J. and Thompson, S. (2005). A study examining change in underrepresented student views of engineering as a result of working with engineers in the elementary classroom. Paper presented at 2005 Annual Conference, Portland, Oregon.

Miles, M. B. and Huberman, A. M. (2015). Nitel veri analiz̧i [Qualitative data analysis] (2. baskıdan çeviri), (S. Akbaba Altun ve A. Ersoy Çev. Eds). Ankara: Pegem Akademi.

Moore, T. J., Stohlmann, M. S., Wang, H. H., Tank, K. M., Glancy, A. W. and Roehrig, G. H. (2014). Implementation and integration of engineering in K-12 STEM education. In Engineering in pre-college settings: Synthesizing research, policy, and practices. Purdue University Press. https://doi.org/10.2307/j.ctt6wq7bh.7

National Research Council. (2009). Engineering in K-12 education: Understanding the status and improving the prospects. National Academies Press.

Pekmez, E., Yılmaz, H., Alaçam Akşit, C. A. and Güler, F. (2017). An Application of a Module on the Development of Science-Technology-Design Process Skills for Primary School Students. Ege Journal of Education, 19(1), 135160. https://doi.org/10.12984/egeefd.343374

Rehmat, A. P. (2015). Engineering the path to higher-order thinking in elementary education: A problem-based learning approach for STEM integration. University of Nevada. Las Vegas, August 2015, 203 pp. (Doctoral Dissertation)

Sadler, P. M., Coyle, H. P. and Schwartz, M. (2000). Engineering competitions in the middle school classroom: Key elements in developing effective design challenges. The Journal of the Learning Sciences, 9(3), $299-327$. https://doi.org/10.1207/S15327809JLS0903_3

Smith, K. A. and Starfield, A. M. (1993). Building models to solve problems. Teaching Critical Thinking: Reports from Across the Curriculum, Englewood Cliffs, NJ: Prentice-Hall, 254-264.

Yıldırım, A. and Şimşek, H. (2013). Sosyal bilimlerde nitel araştırma yöntemleri QQualitative research methods in the social sciences]. Ankara: Seçkin Publishing. 